\title{
Isolation and Characterization of Protease Producing Bacteria from Soil, in Arba Minch University, Abaya Campus
}

\author{
Temam Abrar Hamza \\ Biotechnology Program, Department of Biology, College of Natural Sciences Arba Minch University, Arba Minch, Ethiopia
}

\section{Email address:}

temam2abrar2@gmail.com

\section{To cite this article:}

Temam Abrar Hamza. Isolation and Characterization of Protease Producing Bacteria from Soil, in Arba Minch University, Abaya Campus. American Journal of Biological and Environmental Statistics. Vol. 4, No. 1, 2018, pp. 10-14. doi: 10.11648/j.ajbes.20180401.12

Received: June 8, 2017; Accepted: June 23, 2017; Published: January 15, 2018

\begin{abstract}
Microbes are ubiquitous and live in familiar settings such as soil, water, food and animal intestines as well as in more extreme setting such as rocks, glaciers, hot springs and deep-sea vents. They are essential component of the biodiversity as they account for $50 \%$ of the living biomass of this planet. The aim of this work was isolation and screening of protease producing bacteria from soil collected from the study area. Isolation of protease producing bacteria was performed by the serial dilution and spread plate technique using skim milk agar medium. Accordingly, 131 isolates were positive on skim milk agar and of which $13(10 \%)$ of them are protease producer. Four best isolates were selected on the basis of their clear zone size, one from each site for further study. IS-4 has larger clear zone size with $10.5 \mathrm{~mm}$ followed by IS-2 $(6 \mathrm{~mm})$. All potential isolates have circular in shape of colony and flat in height of colony except IS-1 which is irregular and raised respectively. Most of potential isolates have opaque in their colonial optical density. All isolates were found to be Gram positive and spore producers. Morphological and biochemical results have revealed that three of four active enzyme producing bacteria are identified as Bacillus spp. Members of the genus Bacillus produce a large variety of extracellular enzymes (proteases) particularly significant for industrial application.
\end{abstract}

Keywords: Protease, Bacteria, Isolation, Clear Zone

\section{Introduction}

Microorganisms (or Microbes) are living organisms that are too small to be seen by the unaided eye which include bacteria, fungi, protozoa, microalgae, viruses and helmints. Microbes are ubiquitous and live in familar settings such as soil, water, food and animal intestines as well as in more extreme setting such as rocks, glaciers, hot springs and deepsea vents. They are essential component of the biodiversity as they account for $50 \%$ of the living biomass of this planet. they have profound impact in every face of human life and every things around us because they can be either beneficial in several ways or become a threat to the plant, animal and human health [1].

Microorganisms elaborate a large array of proteases, which are intracellular and/or extracellular. Intracellular proteases are important for various cellular and metabolic processes, such as sporulation and differentiation, protein turnover, maturation of enzymes and hormones and maintenance of the cellular protein pool. Extracellular proteases are important for the hydrolysis of proteins in cell-free environments and enable the cell to absorb and utilize hydrolytic products. At the same time, these extracellular proteases have also been commercially exploited to assist protein degradation in various industrial processes [2, 3].

The global market for industrial enzymes is forecast to reach US\$ 3.74 billion by 2015 . Proteases constitute the largest product segment in the global industrial enzymes sales in various industrial market sectors such as detergent, food, pharmaceutical, leather, diagnostics, waste management and silver recovery [4, 5]. Considering this market demand, there is a need to effort to solve this problem by investigating new microorganisms because they are the major sources of all commercially important alkaline proteases, which have unlimited industrial applications [6-8].

Microorganisms have still potential to produce enzymes, 
even though production cost of the enzyme is the critical issue for further application at industrial level. Substrates from agro-industrial wastes such as Banana peel, cow dung, sugar cane bagasse, Coconut cake, Groundnut and so on are cheap and readily available growth substrates [1]. Therefore, the feasibility of enzyme production on low cost fermentable substrates needs to be studied. These greatly reduce the production cost beside the removal of these undesirable wastes which indirectly minimize environmental pollution [9].

Despite the vast microbial diversity of Ethiopia, Protease producing bacteria have not yet been explored especially from Arba Minch University, Abaya campus. Therefore a research project has been initiated with the this objective.

\section{Methodology}

\subsection{Description of the Study Area}

Arba Minch, ("forty springs") is a city and separate worded in southern Ethiopia; the first common name for this city was GantaGaro. Located in the Gamo Gofa Zone of the Southern Nations, Nationalities, and Peoples Region about 500 kilometers south of Addis Ababa, at an elevation of 1285 meters above sea level. is the largest town in GamoGofa Zone and the second town in Southern Nations, Nationalities and peoples Region ( SNNPR ) next to hawassa. Is located to the west of lake Abaya the annual rainfall in Arba Minch ranges from $623.5 \mathrm{~mm}$ to $1061 \mathrm{~mm}$ and the temperature is $32^{\circ} \mathrm{C}$ the altitude ranges from 2200 to $1400 \mathrm{~m}$ above sea level the most common vegetation type grow in Arbaminch are mango tree, banana and acacia plants.

Arba Minch University (AMU) is one of the wellestablished universities found in the Southern Nations, Nationalities and People's Region (SNNPR). It is located at Arba Minch town. The main campus of the university is situated at the eastern foot of Gamo mountain ranges and adjacent to the vast low land stretching towards Lake Abaya and Lake Chamo which form part of the East African Rift Valley. This study was conducted in ArbaMinch University particularly abaya campus. The study were focus on the isolation and screening, of protease producing bacteria from soil collected from different site of Abaya campus.

\subsection{Sample Collection and Isolation of Proteolytic Bacteria}

Samples were collected from different environments around Abaya campus like student caféteria waste, male and female student dormitary, around class room and library. Each sample was kept in clean sterile sample bottles sealed and transferred to Microbiology and parasitology laboratory and stored at $4^{\circ} \mathrm{C}$.

\subsection{Isolation of Proteolytic Bacteria}

The soil and water samples were suspended in water by vigorous vortexing and serial dilutions were made up to $10^{-6}$ in sterile distilled water. $0.1 \mathrm{ml}$ of appropriate dilution were added to petri plate on skim milk agar plate containing peptone $(0.1 \%), \mathrm{NaCl}(0.5 \%)$, Agar $(2 \%)$ and skimmed milk $(10 \%)$ and incubated at $40^{\circ} \mathrm{C}$ for three days. Proteolytic bacteria were screened. A clear zone formation around the colonies due to skim milk hydrolysis indicated protease production by the microbes. These colonies were picked and purified by streaking on skim milk agar. The cultures were subsequently sub-cultured and used regularly. Agar slants were prepared and preserved at $7^{\circ} \mathrm{C}$ for short term storage for further experiments.

\subsection{Screening and Selection of Potential Isolate from Each Site}

The bacterial strains were screened based on the size of clear zone formed on the skimmed milk agar plate. of enzyme produced under submerged condition. The size of clear zone from each isolate was measured using ruler. A bacterial strain with larger clear zone was screened and selected for further study from each site. Finally various biochemical studies were undertaken according to Bergey's manual of determinative bacteriology for identification of the selected potential isolate.

\subsection{Characterization of Potential Isolates}

Pure cultures of each bacterial isolate from each site was identified on the basis of its colonial morphology, cellular morphology and biochemical characteristics according to the taxonomic scheme of Bergey's Manual of Determinative Bacteriology [10]. Colony morphology characterized using microscope by direct observation of the overnight grown microorganisms on skim milk agar plate.

\subsection{Data Analysis}

The data were analyzed using basic statistical parameters like table and percentage. In addition to this, Microsoft office Excel worksheet 2010 was used for construct and presentation tables.

\section{Results}

\subsection{Isoloation of Proteolytic Bacteria}

One hundred thrity one (131) isolates were obtained from composite soil sample. Out of 131, 13 bacterial isolates were found to be protease producer since they form clear zone around the colony (Table 1). Four potential isolates were selected one from each site on the basis of clear zone size for further study.

As shown in the Table 1, relatively large number of protease producing bacteria, 5 and 4 were isolated from site- 1 and site- 4 respectively. IS-4 show higher proteolytic activity with a clear zone diameter of $10.5 \mathrm{~mm}$ (Figure 1). 
Table 1. Isolation of protease producing Bacteria from soil.

\begin{tabular}{|c|c|c|c|c|c|c|}
\hline S.NO. & Site & Total number of colony & Number of clear zone forming isolate & Dilution factor & Selected isolate & Code \\
\hline 1 & Site-1 & 47 & 5 & $10^{-5}$ & 1 & IS-1 \\
\hline 2 & Site-2 & 13 & 2 & $10-5$ & 1 & IS-2 \\
\hline 3 & Site-3 & 6 & 2 & $10^{-5}$ & 1 & IS-3 \\
\hline 4 & Site-4 & 65 & 4 & $10^{-5}$ & 1 & IS-4 \\
\hline
\end{tabular}

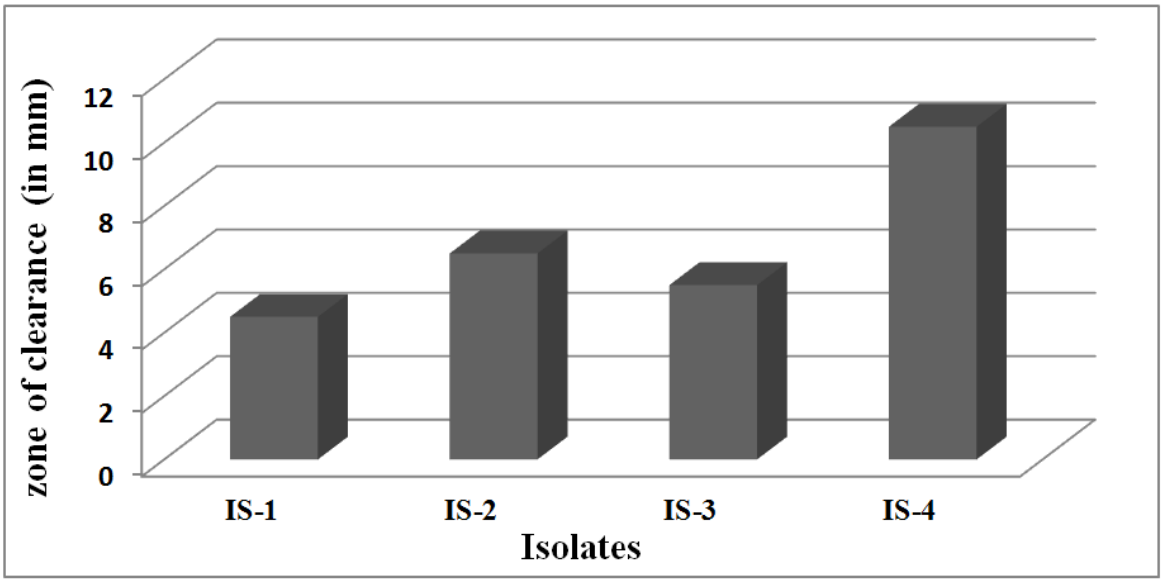

Figure 1. Size of clear zone of proteolytic assay on skim milk agar.

\subsection{Morphological Characteristics of Selected Isolates}

Table 2 show the results of morphological charactersrics and colonial appearance of the selected isolates from each location. All potential isolate have circular in shape of colony and flat in height of colony except IS-1 which is irregular and raised respectively. The colonies of the three isolates (IS-1, 2 and 3) were characterized as opaque, however, IS-4 has transelucent in their optical density.

Table 2. Results of colony characteristics of potential isolate.

\begin{tabular}{|c|c|c|c|c|c|}
\hline Isolate code & Colony surface & Colony colour & Shape of colony & Elavation & Optical density \\
\hline IS-1 & Rough & Whitish & Irregular & Raised & Opaque \\
\hline IS-2 & Smooth & Yellow & Circular & Flat & Opaque \\
\hline IS-3 & Smooth & Whitish & Circular & Flat & Opaque \\
\hline IS-4 & Smooth & Whitish & Circular & Flat & Transelucent \\
\hline
\end{tabular}

\subsection{Physiological and Biochemical Characteristics of Isolates}

All isolates were characterized as Gram positive and spore producer as shown in Figure 2. Only IS-3 was not form bubble on slide smear when three drop of 3\% Hydrogen peroxid added. Motile, Non-motile and rod or cocci shaped cells were observed under light microscope by adding immersion oil with objective lense (1000X magnification). Based on this and acoording to the methods described in Bergey`s Manual of Determinative Bacteriology, the three potential isolate (IS-1, 2 and 3) was designated as Bacillus spp. (Table 3).
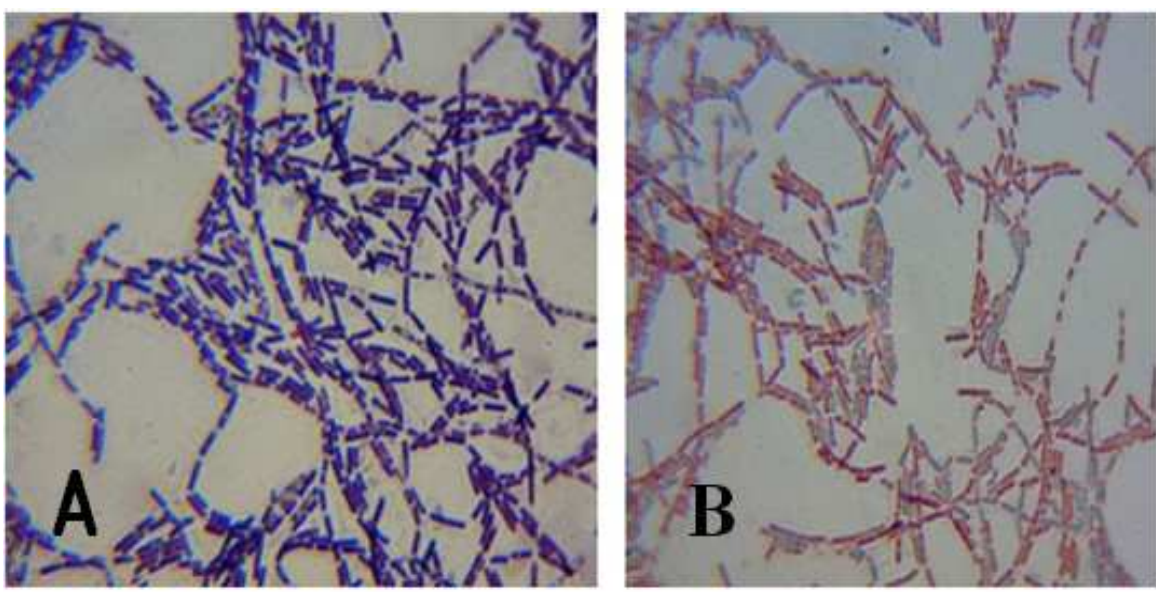

Figure 2. Gram reaction result (+ve) (A) and endospore test (+ve) of Isolate-1 on milk agar. 
Table 3. Biochemical characterization of isolates.

\begin{tabular}{|c|c|c|c|c|c|c|}
\hline Isolate code & Gram Reaction & Spore test & Cell shape & Catalase test & Motililty test & Probably Genus of the isolate \\
\hline Isolate-1 & Positive & Positive & Rod & Positive & Non-motile & Bacillus \\
\hline Isolate-2 & Positive & Positive & Rod & Positive & Motile & Baccillus \\
\hline Isolate-3 & Positive & Positive & Rod & Negative & Motile & Baccillus \\
\hline Isolate-4 & Positive & Positive & cocci & Positive & Motile & Unknown \\
\hline
\end{tabular}

\section{Discussion}

Proteolytic bacteria are wide spread in nature and are able to isolate them from any ecological entities like soil, water, leaves, marine enviroment and waste and wastewater, However, soil is vast reservior of diverse microorganism. Isolation of protease producing bacteria was performed by the serial dilution spread plate technique (2).

One of the main concerns of this study was to isolate and identify bacteria having a vital ability to secrete extra-cellular proteolytic enzyme to be used in different industries. In line of this, 131 bacterial strains were isolated from four different site in Arba Minch University, Abaya campus. Out of 131 isolates, $13(10 \%)$ were screened as protease positive strains (Table 1). Formation of clear zone around the bacterial colony indicated the protease positive strains hydrolysed the skim milk present in the media. Four isolates one from each site were screened on the basis of clear zone size. The use of alkaline skim milk agar for the isolation of alkaline protease producing bacteria has earlier been reported by some workers [11]. Results show that, Site-1 is rich in proteolytic bacteria. This indicates that Site-1 has potential for screening of bacterial strain which produce industrially important enzymes like protease.

Among the four best selected strain, IS-4 and IS-2 were showed good proteolytic activity. However, IS-1 and IS-3 were exhibited relatively moderate proteolytic activity. IS-4 has larger clear zone than the others, indicating higher proteases activity (Figure 1).

In the present study, All (100\%) of the selected strain were Gram positive and spore producer (Table 2 and Figure 2). This indicate that they have thick peptidoglycan layer in their cell wall structure. Identification of selected bacterial strains were identified on the basis of standard morphological and biochemical tests according to the method described in Bergey's Manual of Determinative Bacteriology. In addition to this, structural, staining and biochemical activity results revealed that three of four active enzyme producing bacteria are Bacillus spp. (Table 3). Members of the genus Bacillus produce a large variety of extracellular enzymes (proteases) which have particularly significant industrial application. This finding was in accordance with well documented reports in literature for protease isolation and production of proteases [12-15].

\section{Conclusions}

Based on the results obtained from this study, the following conclusions could be drawn:

The primary and most crucial step to get a good protease producer is identification and selection of potential isolates. From each location one best representative strain (IS-1,2,3 and 4) were selected. They were good source of protease as they showed high proteolytic activity. Protease producing microorganisms have many roles in different industries and environmental bioremediation by degrading protein containing compounds. The use of microorganisms to produce enzymes has a number of technical and economic advantages and in recent years has become the predominant mode of enzyme production. All potential strains isolated in this study have potential for industrial applications. Enzymes are widely used in several industries, notably in detergent, food processing, brewing and pharmaceutical industries. They are also used for diagnostic, scientific and analytical purposes.

\section{References}

[1] Aguilar, C. N., Gutiérrez, G., Lilia, P. A., Rado, R. H. R., Martínez, J. L. and Contreras, J. C. Perspectives of solid state fermentation for production of food enzymes. American Journal of Biochemistry and Biotechnology. 2008;4:12.

[2] Fekadu Alemu. Isolation and screening of protease producing bacteria from cheese. International Journal of Nutrition and Food Science. 2015;4:6.

[3] Temam, A. H.. Bacterial Protease Enzyme: Safe and Good Alternative for Industrial and Commercial Use. International Journal of Chemical and Biomolecular Science. 2017. 3(1): 110 .

[4] Kanmani, R., Dhivya, S., Jayalakshmi, S. and Vijayabaskar, P. Studies on detergent additives of protease enzyme from an estuarine bacterium Bacillus cereus. International Research Journal of Biotechnology. 2011;2:7.

[5] Kumar, D. J. M., Rajan, R., Lawrence, L., priyadarshini, S. and Kalaichelvan, P. T. Destaning and dehairing capability of partially purified Bacillus subtilisprotease from optimized fermentation medium. Asian Journal of Experimental and Biological Science. 2012;3:7.

[6] Gupta, R.; Beg, Q. K. and Lorenz, P. Bacterial alkaline proteases: molecular approaches and industrial applications. Applied Microbiology and Biotechnology. 2002;59:17.

[7] Temam, A. H. Isolation and Screening of Protease Producing Bacteria from Local Environment for Detergent Additive, American Journal of Life sciences. 2017. 5(5):116-124.

[8] Bholay, A. D., More, S. Y., Patil, V. B. and Patil, N. Bacterial extracellular alkaline proteases and its industrial applications. International Research Journal of Biological Sciences. 2012;1:5.

[9] Temam, A. H. Isolation of Protease Producing Bacteria from Soil for Polyester and Silver Recovery from Waste X-ray Film. American Journal of BioScience. 2017. 5(5):74-79. 
[10] Bergey, D. H. and Holt, J. G. Bergey's manual of determinative bacteriology, 9th edition Williams and Wilkins, Baltimore. 9th edition Williams and Wilkins, Baltimore. 1994.

[11] Haile, G. and Gessesse A. Properties of alkaline protease C45 produced by alkaliphilic Bacillus Sp. isolated from Chitu, Ethiopian Soda Lake. Journal of Biotechnology and Biomaterial. 2012;2:4.

[12] Singh, P., Rani, A. and. Chaudhary, N. Isolation and characterization of protease producing Bacillus sp from soil. International Journal of Pharma Sciences and Research. 2015;6:6.
[13] Najafi, M. F. Potential application of protease isolated from Pseudomonas aeruginosa PD100. Electronic Journal of Biotechnology. 2005;8:6.

[14] Temam, A. H. and Fantahun, W. Optimization of Culture Growth Parameters for Production of Protease from Bacteria, Isolated from Soil. Bioscience and Bioengineering. 2017. 3(1):1-10.

[15] Prabhavathy, G., Rajasekara, M., Pandian and Senthilkumar, B. Identification of industrially important alkaline protease producing Bacillus subtilis by 16s rRNA sequence analysis and its applications. International Journal of Research in Pharmaceutical and Biomedical Sciences. 2013;4:6. 